\title{
Pengaruh Tingkat Persediaan Terhadap Rentabilitas Ekonomi Pada PT Sepatu Bata, Tbk
}

\author{
Popon Rabia Adawia ${ }^{1}$, Ayu Azizah ${ }^{2}$ \\ 1) Universitas Bina Sarana Informatika \\ popon.pra@bsi.ac.id \\ ${ }^{2)}$ Universitas Bina Sarana Informatika \\ ayu.azz@bsi.ac.id
}

(Adawia \& Azizah, 2019)

Adawia, P. R., \& Azizah, A. (2019). Pengaruh Tingkat Persediaan Terhadap Rentabilitas Ekonomi Pada PT Sepatu Bata, Tbk. Moneter, 6(2), 167-172.

\begin{abstract}
This study examines the effect of inventory levels on economic rentability at PT Sepatu Bata Tbk. Referring to two variables, namely economic rentability as the dependent variable / dependent variable $(x)$ and inventory level as independent variables / independent variables (y). The purpose of this research is to find out whether or not there is a positive and significant influence between inventory level rotation, economic profitability at PT Sepatu Bata Tbk, and to find out how much influence the inventory level has on economic rentability. The research method used in carrying out this research is an associative research method which aims to determine the influence of the two variables studied. This study uses simple linear regression data analysis techniques, while for the hypothesis test statistical tests are carried out with the $T$ test. For the regression equation obtained is $Y=18.72-0.23 X$. This study concludes that the inventory does not significantly influence the economic rentability of PT Sepatu Bata Tbk. These results can be seen from tcount of -1.585 and ttable of 2.015, which means that tcount is smaller than ttable. While the influence of inventory variables on economic rentability is $33.4 \%$ while the remaining $66.6 \%$ is influenced by other variables outside of this study.
\end{abstract}

Keywords: Inventory, economic rentability, profitability

\section{PENDAHULUAN}

Perusahaan merupakan salah satu sarana yang dapat menunjang program pemerintah dibidang perekonomian. Seiring dengan perkembangan dunia usaha yang semakin pesat ini akan membawa dampak persaingan perdagangan yang ketat, terutama pada perusahaan sejenis. Dengan demikian perusahaan dituntut bekerja lebih efisien supaya dapat tetap bertahan dalam bidangnya masingmasing.

Dilihat dari segi globalisasi persaingan lebih tajam karena untuk masuk ke dalam pasar global, banyak faktor-faktor yang harus ditingkatkan dan diperbaiki. Faktor-faktor tersebut adalah kualitas, ketepatan waktu, dan tentu saja modal. Persaingan global yang dihadapi perusahaan tersebut memaksa para manajemen perusahaan untuk mengambil keputusan yang berkualitas berdasarkan fakta-fakta. Laba atau profit merupakan salah satu tujuan utama berdirinya setiap badan usaha. Tanpa diperolehnya laba, perusahaan tidak dapat memenuhi tujuan lainnya, yaitu pertumbuhan yang terus-menerus (going concern) dan tanggung jawab sosial (corporate social responsibility). Bagi perusahaan yang berorientasi laba, pasti akan selalu berusaha untuk meningkatkan laba yang diperolehnya. Segala macam cara akan ditempuh untuk mendapatkan laba yang lebih besar. Menurut (Hanafi, 2010), laba adalah ukuran keseluruhan prestasi perusahaan yang didefinisikan sebagai berikut: laba = pendapatan biaya. Kelangsungan hidup perusahaan (going concern) dipengaruhi oleh banyak hal antara lain aspek keuangan yang mencerminkan keberhasilan kinerja perusahaan. Aspek keuangan salah satunya dapat terlihat didalam laba (Suratminingsih, 2018).

Rasio rentabilitas atau yang dikenal juga dengan rasio profitabilitas merupakan rasio yang menggambarkan kemampuan perusahaan dalam menghasilkan laba melalui semua kemampuan dan sumber daya yang dimilikinya (Hery, 2015). Dengan kata lain rentabilitas adalah kemampuan perusahaan untuk menghasikan laba selama periode tertentu (Riyanto, 2016). Bagi perusahaan pada umumnya masalah rentabilitas lebih penting dari pada masalah laba, karena laba yang besar saja belum cukup untuk mengukur apakah perusahaan tersebut telah bekerja dengan efisien atau belum. Efisien baru dapat 
diketahui dengan membandingkan laba yang diperoleh itu dengan kekayaan atau modal yang menghasilkan laba tersebut, atau dengan kata lain ialah menghitung rentabilitasnya. Bagi perusahaan rentabilitas merupakan kemampuan manajemen dalam menggunakan operating assets secara efisien dan mampu memperoleh laba sebesar-besarnya, sehingga perusahaan dapat menjalankan produksi/usaha dengan lancar dan tidak mengalami hambatan. Dengan demikian maka yang harus diperhatikan oleh perusahaan adalah tidak hanya bagaimana usaha untuk memperbesar laba, tetapi yang lebih penting ialah usaha untuk mempertinggi dan memaksimalkan rentabilitasnya. Untuk dapat mencapai tingkat rentabilitas yang maksimal dari suatu perusahaan tidak lepas dari pengelolaan modal kerja.

Persediaan adalah elemen modal kerja yang sangat penting pengelolaannya untuk mencapai tingkat rentabilitas yang maksimal. Persediaan sebagai salah satu aktiva perusahaan yang menempati posisi yang cukup penting dalam suatu perusahaan, baik itu perusahaan dagang maupun manufaktur. Sebagaimana dikemukakan oleh Yunus dalam (Adawia, 2018) bahwa persediaan dikategorikan sebagai barang dagangan yang dimiliki dan disimpan untuk dijual kepada pelanggan (customer). Dimana harga pokok penjualan atas barang dagang yang dijual merupakan pengurang terbesar dari hasil penjualan tersebut yang nantinya akan mempengaruhi laba bersih perusahaan.Semakin tinggi tingkat persediaan menunjukkan semakin tingginya volume penjualan. Dengan demikian resiko serta biaya persediaan dapat diminimalkan, misalnya biaya penyimpanan, biaya pemeliharaan serta resiko susut atau kerusakan. Semakin tinggi laba yang diterima maka tinggi pula rentabilitas ekonomi.

Berdasarkan uraian di atas, penulis melakukan penelitian yang berhubungan dengan tingkat persediaan terhadap tingkat pencapaian profitabilitas, dalam hal ini adalah rentabilitas ekonomi dari tahun 2009 sampai dengan tahun 2016 pada PT. Sepatu Bata, Tbk.

\section{METODOLOGI PENELITIAN}

\section{Tempat dan Waktu Penelitian}

Jenis penelitian ini merupakan penelitian yang bersifat asosiatif dengan jenis kausal yaitu hubungan yang bersifat sebab akibat (pengaruh). Penelitian ini menjadikan PT Bata Tbk sebagai objek penelitian dengan mengambil data laporan keuangan pada Bursa Efek Indonesia (BEI) dari tahun 2009 sampai dengan tahun 2016.

\section{Jenis dan Sumber Data}

Penelitian ini termasuk dalam penelitian asosiatif kuantitatif, yaitu data yang diperoleh dari sampel populasi penelitian dianalisis sesuai dengan metode statistik yang digunakan kemudian diinterprestasikan. Untuk sumber data merupakan data sekunder. Data sekunder diperoleh secara tidak langsung dari objek penelitian. Peneliti mendapatkan data yang sudah jadi yang dikumpulkan oleh pihak lain dengan berbagai cara atau metode baik secara komersial maupun non komersial.

\section{Populasi dan Sampel}

a. Populasi

Menurut (Sugiyono, 2012) populasi merupakan wilayah generalisasi yang terdiri atas objek/subjek yang mempunyai kualitas dan karakteristik tertentu yang ditetapkan oleh peneliti untuk dipelajari dan kemudian ditarik kesimpulannya. Jadi populasi bukan hanya orang tapi juga objek dan benda-benda alam yang lain. Populasi juga bukan sekedar jumlah yang ada pada objek/subjek yang dipelajari, tetapi meliputi karakteristik/sifat yang dimiliki oleh objek/subjek itu. Populasi dalam penelitian ini adalah data keuangan tahunan perusahaan manufaktur yang tercatat pada Bursa Efek Indonesia (BEI).

b. Sampel

Sampel merupakan bagian dari jumlah dan karakteristik tang dimiliki oleh populasi tersebut (Sugiyono, 2012). Sampel dalam penelitian ini adalah keseluruhan data dan informasi keuangan PT Sepatu Bata Tbk. mulai dari tahun 2009 sampai dengan tahun 2016 yang diambil dari Bursa Efek Indonesia (BEI). Teknik pengambilan sampel dalam penelitian ini adalah purposive, yaitu dengan kriteria-kriteria berikut :

1) Perusahaan tersebut merupakan perusahaan manufaktur yang terdaftar di Bursa Efek Indonesia.

2) Memiliki kelengkapan informasi yang dibutuhkan terkait dengan indikator indikator perhitungan yang dijadikan variabel pada penelitian ini.

\section{Metode Pengumpulan Data}

Prosedur pengumpulan data adalah langkah-langkah untuk memperoleh data dan keterangan yang diperlukan dalam penelitian. Untuk menunjang hasil penelitian tersebut, maka penulis melakukan pengumpulan data yang diperlukan dengan cara :

a. Metode Kepustakaan

Metode kepustakaan digunakan untuk melengkapi landasan teori yang dilakukan dengan cara membaca buku pustaka, referensi koran, serta hasil penelitian terdahulu agar diperoleh pengetahuan tentang yang diteliti sehingga dapat memecahkan masalah penelitian dengan cara yang cepat dan tepat.

b. Dokumentasi 
Yaitu suatu langkah pengupulan data yang dilakukan dengan cara mengumpulkan dan menganalisis dokumen-dokumen yang berhubungan dengan masalah yang akan diuraikan dalam penelitian. Dokumen tersebut berupa data informasi keuangan PT Sepatu Bata Tbk. yang diperoleh dari Bursa Efek Indonesia (BEI).

c. Hipotesis Statistik

Berdasarkan hipotesis yang telah dikemukakan, maka bentuk pengujian hipotesis yang akan diuji dalam penelitian ini dapat dirumuskan sebagai berikut :

Ho : $\beta=0$, tidak terdapat pengaruh yang positif dan signifikan antara tingkat persediaan dengan rentabilitas ekonomi PT Sepatu Bata Tbk.

Ha : $\beta \neq 0$, terdapat pengaruh yang positif dan signifikan antara tingkat persediaan dengan rentabilitas ekonomi PT Sepatu Bata Tbk.

\section{Teknik Analisis Data}

Penelitian ini menggunakan teknik analisis data regresi linier sederhana, sedangkan untuk uji hipotesis dilakukan test statistik dengan uji T. Selain itu digunakan uji koefisien determinasi untuk mengetahui besarnya variasi yang diturunkan oleh variabel $\mathrm{X}$, dalam penelitian ini adalah data time series. Menurut (Umar, 2014) data time series merupakan sekumpulan data dari suatu fenomena tertentu yang didapat dalam beberapa interval waktu tertentu, misalnya dalam waktu mingguan, bulanan, ataupun tahunan.

a. Analisis Regresi Linier Sederhana

Untuk mencari seberapa besar perhitungan tingkat persediaan dan pengaruhnya terhadap rentabilitas ekonomi dengan menggunakan analisis regresi sederhana. Analisis regresi linier sederhana adalah hubungan secara linier antara satu variabel independen ( $x$ ) dengan variabel dependen (y). Analisis ini untuk mengetahui arah hubungan antara variabel independen dengan variabel dependen apakah positif atau negatif dan untuk memprediksi nilai dari variabel dependen apabila nilai variabel independen mengalami kenaikan atau penurunan. Data yang digunakan biasanya berskala interval. Rumus regresi linier sederhana sebagai berikut:

$$
\mathrm{Y}=\mathrm{a}+\mathrm{bx}
$$

Sumber : (Sugiyono, 2012)

Dimana:

$\mathrm{Y}=$ variabel tak bebas

$\mathrm{a}=$ bilangan berkonstanta

$\mathrm{b}=$ koefisien arah garis

$\mathrm{X}=$ variabel bebas $\mathrm{X}$

Dimana nilai a dan $\mathrm{b}$ dapat dicari dengan rumus sebagai berikut :

$a=\frac{\left(\sum y\right)-b\left(\sum x\right)}{n}$

$$
b=\frac{n\left(\sum x y\right)-\left(\sum x\right)\left(\sum y\right)}{n\left(\sum_{x} 2\right)-\left(\sum x\right)^{2}}
$$

b. Koefisien Korelasi Parsial

Korelasi adalah indeks atau bilangan yang digunakan untuk mengukur derajat hubungan, meliputi kekuatan hubungan dan bentuk atau arah hubungan. Untuk mengetahui perhitungan tingkat persediaan dan hubungannya terhadap rentabilitas ekonomi PT Sepatu Bata Tbk. digunakan analisis korelasi dengan rumus product moment yaitu sebagai berikut :

$$
r y x=\frac{n \sum x y-\left(\sum x\right)\left(\sum y\right)}{\sqrt{\left(n \sum x^{2}-\left(\sum x\right)^{2}\right)\left(n \Sigma y^{2}-(\Sigma y)^{2}\right)}}
$$

Keterangan:

$\mathrm{Y}=$ Variabel dependen

$\mathrm{X}=$ Variabel Independen

$\mathrm{n}=$ Jumlah data

$\mathrm{b}=$ Koefisien korelasi

c. Koefisien Determinasi

Koefisien determinasi adalah angka atau indeks yang digunakan untuk mengetahui besar kecilnya pengaruh variabel bebas terhadap variasi (naik/turunnya) variabel terikat. Koefisisen determinasi ini digunakan untuk mengetahui besarnya pengaruh perhitungan tingkat persediaan terhadap rentabilitas ekonomi yang dapat ditentukan dengan rumus koefisien determinasi (coefficient of determination) sebagai berikut :

$$
\mathrm{KD}=\mathrm{r}^{2} \times 100 \%
$$

Keterangan:

$\mathrm{KD}=$ Nilai Koefisien Determinasi

$\mathrm{r} \quad=$ Nilai Koefisien kolerasi

d. Uji Hipotesis (Uji t)

Untuk menentukan atau menyimpulkan hasil penelitian, maka perlu diuji terlebih dahulu apakah $\mathrm{r}$ (koefisien korelasi) yang telah dilakukan diatas berarti atau tidak. Untuk mengetahui keberartian koefisien korelasi tersebut digunakan uji t dengan rumus :

$$
\text { Keterangan : } \begin{aligned}
\mathrm{t} & =\text { Nilai uji } \mathrm{t} \\
\mathrm{r} & =\text { Koefisien korelasi } \\
\mathrm{n} & =\text { Jumlah sampel }
\end{aligned}
$$$$
t \text { hit }=\frac{\sqrt[r]{(n-2)}}{\sqrt{1-r^{2}}}
$$

Dengan ketentuan tingkat $\operatorname{kesalahan}(\alpha)=0,05$

dengan rumus: derajat bebas $(\mathrm{db})=\mathrm{n}-2$

Dengan criteria pengujian sebagai berikut:

- Ho diterima jika thitung < ttabel

- Ho ditolak jika thitung $>$ t tabel 


\section{HASIL DAN PEMBAHASAN}

Dalam menganalisis peneliti mengunakan data tingkat persediaan dan rentabilitas.

\section{Analisis Tingkat Persediaan PT Sepatu Bata Tbk}

Tingkat persediaan menunjukkan persentase seberapa besar kenaikan atau penurunan nilai persediaan dalam kurun waktu tertentu. Jadi untuk mengetahui nilai tingkat persediaan PT Sepatu Bata Tbk. yaitu menghitung nilai kenaikan atau penurunan persediaan tahun sebelumnya dengan nilai persediaan setelahnya lalu dibandingkan dengan nilai persediaan tahun setelahnya.

Berikut merupakan perhitungan tingkat persediaan PT Sepatu Bata Tbk dari tahun 2010 hingga tahun 2016.

\begin{tabular}{cc}
$\begin{array}{c}\text { Tabel } 1 . \text { Persediaan PT. Sepatu Bata Tbk } \\
\text { Tahun } 2009-2016 \\
\text { (dalam ribuan Rp) }\end{array}$ \\
\hline Tahun & Jumlah Persediaan \\
\hline $\mathbf{2 0 0 9}$ & 153.761 .143 \\
$\mathbf{2 0 1 0}$ & 191.217 .901 \\
$\mathbf{2 0 1 1}$ & 193.997 .433 \\
$\mathbf{2 0 1 2}$ & 221.854 .075 \\
$\mathbf{2 0 1 3}$ & 281.405 .718 \\
$\mathbf{2 0 1 4}$ & 314.628 .156 \\
$\mathbf{2 0 1 5}$ & 282.546 .591 \\
$\mathbf{2 0 1 6}$ & 324.917 .517 \\
\hline
\end{tabular}

Sumber : Laporan Keuangan PT. Sepatu Bata Tbk periode $2009-2016$

Sedangkan unuk tingkat persediaan tahun 2010 sampai dengan tahun 2016 sebagai variabel $\mathrm{X}$ adalah sebagai berikut:.

Tabel 2. Tingkat Persediaan PT. Sepatu Bata Tbk Tahun 2010-2016

\begin{tabular}{cc}
\hline Tahun & Nilai Tingkat Persediaan (\%) \\
\hline 2010 & 24.36 \\
2011 & 1.45 \\
2012 & 14.36 \\
2013 & 26.84 \\
2014 & 11.81 \\
2015 & -10.20 \\
2016 & 15.00 \\
\hline
\end{tabular}

Sumber : pengolahan data Laporan Keuangan PT. Sepatu Bata Tbk periode 2009 - 2016

Berdasarkan tabel di atas tampak bahwa tingkat persediaan dari tahun 2009 ke tahun 2010 mengalami kenaikan sebesar $24.36 \%$ dari $\mathrm{Rp}$ 153.761.143 menjadi Rp 191.217.901. Pada tahun 2010 ke tahun 2011 mengalami kenaikan hanya $1.45 \%$ dengan nilai kenaikan $\mathrm{Rp}$ 2.779.532. Dari tahun 2011 ke tahun 2012 mengalami kenaikan persediaan sebesar $14.36 \%$ menjadi Rp 221.854.075. Tahun 2012 ke tahun 2013 mengalami kenaikan sebesar 26.84\% menjadi Rp 281.405.718. Dari tahun 2013 ke tahun 2014 mengalami kenaikan 11.81\%. Kemudian pada tahun 2015 nilai persediaan mengalami penurunan sebesar $10.20 \%$ dari angka Rp 314.628.156 di tahun 2014 menjadi Rp 282.546.591ribu. Tahun 2016 nilai persediaan kembali naik yaitu sebesar $15 \%$ menjadi Rp 324.917.517.

\section{Analisis Tingkat Rentabilitas Ekonomi PT Sepatu Bata Tbk.}

Rentabilitas ekonomi menunjukkan perbandingan antara laba usaha dengan total modal yang digunakan untuk menghasilkan laba.

Tabel dibawah ini merupakan nilai rentabilitas ekonomi (sebagai variabel Y) tahun 2009 sampai dengan tahun 2016.

Tabel 3. Nilai Rentabilitas Ekonomi PT Sepatu Bata Tbk Periode 2009-2016

\begin{tabular}{lccc}
\hline Thn & Laba Usaha & $\begin{array}{c}\text { Total } \\
\text { Modal }\end{array}$ & $\begin{array}{c}\text { Nilai } \\
\text { Rentabilitas } \\
\text { Ekonomi(\% }\end{array}$ \\
& & & ) \\
\hline $\mathbf{2 0 0 9}$ & $52,980,646$ & $301,343,895$ & 17.58 \\
$\mathbf{2 0 1 0}$ & $60,975,070$ & $331,508,965$ & 18.39 \\
$\mathbf{2 0 1 1}$ & $56,615,123$ & $354,480,088$ & 15.97 \\
$\mathbf{2 0 1 2}$ & $69,343,398$ & $387,488,486$ & 17.90 \\
$\mathbf{2 0 1 3}$ & $44,373,679$ & $394,361,411$ & 11.25 \\
$\mathbf{2 0 1 4}$ & $71,246,429$ & $425,597,596$ & 16.74 \\
$\mathbf{2 0 1 5}$ & $129,519,446$ & $547,187,208$ & 23.67 \\
$\mathbf{2 0 1 6}$ & $42,231,663$ & $557,155,279$ & 7.58 \\
\hline Sumber : Laporan Keuangan PT. Sepatu Bata Tbk periode \\
$2009-2016$ data diolah
\end{tabular}

Ditahun 2009 ke 2010 rentabilitas ekonomi PT Sepatu Bata Tbk mengalami kenaikan dari nilai 17.58\% menjadi 18.39\%. Ditahun 2011 rentabilitas ekonomi PT Sepatu Bata Tbk. mengalami penurunan $13.16 \%$ dari tahun sebelumnya, menjadi $15.97 \%$. Ditahun 2012 rentabilitas ekonomi mengalami kenaikan menjadi 17.90\%. Tahun 2013 rentabilitas ekonomi PT Sepatu Bata Tbk. mengalami penurunan $37.15 \%$ menjadi $11.25 \%$. Kemudian ditahun 2014 rentabilitas ekonomi mengalami kenaikan kembali menjadi $16.74 \%$. Dan ditahun 2015 pun mengalami kenaikan $41.4 \%$, dengan nilai rentabilitas ekonomi menjadi 23.67\%. Namun ditahun 2016 mengalami penurunan cukup signifikan yaitu $67.97 \%$ dengan nilai rentabilitas ekonomi hanya menjadi $7.58 \%$.

\section{Analisis Statistik}

Analisis statistik digunakan untuk menunjukkan hubungan variabel independen $(\mathrm{x})$ dengan variabel dependen (y), yaitu dengan menggunakan regresi linier sederhana. Untuk mengetahui suatu persamaan regresi yang dihasilkan baik digunakan uji koefisien korelasi parsial, koefisien determinasi, dan uji T.

a. Analisa Regresi Linier Sederhana

Untuk mengetahui seberapa besar pengaruh tingkat persediaan terhadap rentabilitas ekonomi PT Sepatu Bata Tbk perlu adanya perhitungan regresi sebagai berikut :

$$
\mathrm{Y}=\mathrm{a}+\mathrm{bX} \text {. }
$$

Berdasarkan data yang telah penulis peroleh mengenai hasil perhitungan tingkat persediaan dan rentabilitas ekonomi tahun 2009 sampai 
dengan tahun 2016 yang dianalisis dengan menggunakan program SPSS 21.0 menghasilkan persamaan regresi adalah sebagai berikut:

\begin{tabular}{|c|c|c|c|c|c|}
\hline & \multicolumn{3}{|c|}{$\begin{array}{l}\text { Tabel 4, Hasil Regresi } \\
\text { Coefficients }^{\mathbf{a}}\end{array}$} & & \\
\hline & $\begin{array}{r}\text { Unstan } \\
\text { zec } \\
\text { Coeffic }\end{array}$ & $\begin{array}{l}\text { dardi } \\
\text { ients }\end{array}$ & $\begin{array}{c}\text { Standardize } \\
\mathrm{d} \\
\text { Coefficients }\end{array}$ & & \\
\hline & & $\begin{array}{l}\text { Std. } \\
\text { Erro }\end{array}$ & & & \\
\hline Model & B & $\mathrm{r}$ & Beta & $\mathrm{T}$ & Sig. \\
\hline 1 (Constant) & 18.721 & $\begin{array}{r}2.48 \\
8\end{array}$ & & 7.525 & .001 \\
\hline persediaan & -.234 & .148 & -.578 & -1.585 & .174 \\
\hline
\end{tabular}

a. Dependent Variable: rentabilitas

Jadi, rumus persamaannya yaitu :

$$
\mathrm{Y}=18.72-0.23 \mathrm{X}
$$

Jadi, jika variabel $\mathrm{X}$ bernilai 0 maka nilai variabel $\mathrm{Y}$ adalah 18.72. Dari hasil analisis regresi sederhana diatas dapat diketahui bahwa nilai konstanta $(\alpha)$ sebesar 18,72 dan nilai koefisien regresi (b) sebesar 0,23 maka didapat persamaan regresi linear yaitu $\mathrm{Y}=$ 18,72 - 0,23X adapun interprestasi dari persamaan diatas adalah :

1) $\alpha=18,72$

Nilai konstanta ini menunjukkan bahwa apabila tidak ada perubahan jumlah persediaan $(X=0)$, maka tingkat rentabilitas yang terbentuk adalah sebesar 18,72 .

2) $\mathbf{b}=-0,23$

Koefisien regresi $X$ sebesar -0,23 menyatakan bahwa apabila setiap variabel persediaan meningkat sebesar 1 satuan, maka tingkat rentabilitas menurun sebesar 0.23

b. Analisis Koefisien Kolerasi Product Moment Untuk menguji hipotesis dalam penelitian ini, penulis menggunakan analisa koefisien korelasi (r) dengan rumus metode least square yaitu teknik analisa data untuk mengetahui tingkat hubungan antara variabel X (tingkat persediaan) terhadap variabel Y (rentabilitas ekonomi). Untuk dapat menghitung korelasi, maka penulis melakukan pengolahan data dengan menggunakan program SPSS 21.0 dengan hasil yang diperoleh adalah sebagai berikut:

Tabel 5. Hasil Korelasi

Correlations

\begin{tabular}{rlrr}
\hline & & persediaan & rentabilitas \\
\hline Persediaan & Pearson & 1 & -.578 \\
& Correlation & & \\
& Sig. & & .174 \\
& tailed) & & \\
& $\mathrm{N}$ & 7 & 7 \\
Rentabilitas & Pearson & -.578 & 1 \\
& Correlation & & \\
& Sig. (2- & .174 & \\
& tailed) & & \\
\hline
\end{tabular}

\begin{tabular}{|c|c|c|c|}
\hline \multicolumn{4}{|c|}{ Correlations } \\
\hline & & persediaan & rentabilitas \\
\hline \multirow[t]{3}{*}{ Persediaan } & $\begin{array}{l}\text { Pearson } \\
\text { Correlation }\end{array}$ & 1 & -.578 \\
\hline & $\begin{array}{l}\text { Sig. } \\
\text { tailed })\end{array}$ & & .174 \\
\hline & $\mathrm{N}$ & 7 & 7 \\
\hline \multirow[t]{3}{*}{ Rentabilitas } & $\begin{array}{l}\text { Pearson } \\
\text { Correlation }\end{array}$ & -.578 & 1 \\
\hline & $\begin{array}{l}\text { Sig. } \\
\text { tailed })\end{array}$ & .174 & \\
\hline & $\mathrm{N}$ & 7 & 7 \\
\hline
\end{tabular}

Dari hasil analisis diatas kolerasi diatas diketahui bahwa hubungan negatif antara tingkat persediaan (variabel $\mathrm{X}$ ) dengan rentabilitas ekonomi (variabel $\mathrm{Y}$ ) dengan nilai koefisien kolerasi (r) sebesar -0,578 artinya semakin bertambah tingkat persediaan maka akan dibarengi dengan penurunan jumlah rentabilitas perusahaan. Kemudian dengan nilai kolerasi sebesar -0,578 maka dapat disimpulkan bahwa tingkat kolerasi antara persediaan terhadap rentabilitas adalah cukup kuat.

c. Uji Determinasi (Koefisien Determinasi)

Uji determinasi dilakukan untuk mengetahui pengaruh tingkat persediaan terhadap rentabilitas ekonomi dalam bentuk persentase. Untuk mencari koefisien determinasi maka penulis mengolah data dengan menggunakan program SPSS 21.0 dengan hasil sebagai berikut:

Tabel 6. Hasil Koefisien Determinasi Model Summary

\begin{tabular}{|c|c|c|c|c|}
\hline Model & $\mathrm{R}$ & $\begin{array}{c}\mathrm{R} \\
\text { Square }\end{array}$ & $\begin{array}{l}\text { Adjusted } \\
\text { R Square }\end{array}$ & $\begin{array}{l}\text { Std. Error of } \\
\text { the Estimate }\end{array}$ \\
\hline 1 & $\begin{array}{r}.578 \\
\mathrm{a}\end{array}$ & .334 & .201 & \\
\hline
\end{tabular}

a. Predictors: (Constant), persediaan

Dari hasil di atas dapat disimpulkan bahwa tingkat persediaan hanya berpengaruh sebesar $33.4 \%$ terhadap rentabilitas ekonomi, sementara sisanya yaitu $66,6 \%$ dipengaruhi oleh faktor lainnya.

d. Uji Hipotesis (Uji T)

Untuk menentukan atau menyimpulkan hasil penelitian, maka perlu diuji terlebih dahulu apakah $\mathrm{r}$ (koefisien korelasi) yang telah dilakukan diatas berarti atau tidak. Untuk menguji apakah koefisisen korelasi (r) signifikan atau tidak, maka dilakukan pengujian melalui uji $\mathrm{t}$ dengan menggunakan program SPSS 21.0 maka diperoleh hasil sebagai berikut: 


\begin{tabular}{lcccccc} 
& \multicolumn{3}{c}{$\begin{array}{c}\text { Tabel 7. Uji Statistik } \\
\text { Coefficients }^{\mathbf{a}}\end{array}$} & & \\
\cline { 2 - 4 } & \multicolumn{3}{c}{$\begin{array}{c}\text { Unstandardized } \\
\text { Coefficients }\end{array}$} & $\begin{array}{l}\text { Standardized } \\
\text { Coefficients }\end{array}$ & & \\
\cline { 2 - 4 } Model & $\mathrm{B}$ & Etd. & Error & Beta & T & Sig. \\
1 (Constant) & 18.721 & 2.488 & & 7.525 & .001 \\
persediaan & -.234 & .148 & -.578 & -1.585 & .174 \\
\hline
\end{tabular}

a. Dependent Variable: rentabilitas

Dari hasil analisis diatas, maka dapat diketahui nilai $\mathrm{t}$ hitung adalah sebesar $-1,585$ kemudian untuk menentukan uji hipotesisnya perlu dicari nilai $\mathrm{t}$ tabel menggunakan tabel $\mathrm{T}$, untuk dapat mencari nilai $\mathrm{t}_{\text {tabel }}$ maka perlu diketahui dahulu nilai signifikan $\alpha$ dan nilai derajat bebas atau degree of freedom (DF). Dalam penelitian ini dapat diketahui sebagai berikut:

Derajat bebas $(\mathrm{DF})=\mathrm{n}-2$

$$
(\mathrm{DF})=7-2=5
$$

Tingkat kepercayaan $=95 \%$

$$
\alpha=1-95 \%
$$

Dari taraf signifikan dan derajat bebas yang telah diketahui, maka dapat ditentukan nilai $\mathrm{t}$ tabel pada tabel $\mathrm{T}$ dalam penelitian ini adalah pada kolom signifikan 0,05 dan baris ke-5 yaitu 2,015. Berdasarkan hasil analisis uji $\mathrm{t}$ diatas, dapat diketahui nilai $\mathrm{t}_{\text {hitung }}$ sebesar $-1,585$ dan nilai $\mathrm{t}$ tabel sebesar 2,015 ini menunjukan bahwa nilai $t$ hitung lebih kecil dari pada nilai $\mathrm{t}_{\text {tabel }}\left(\mathrm{t}_{\text {hitung }}<\mathrm{t}\right.$ tabel) yang berarti Ho diterima dan Ha ditolak. Dengan demikian maka dapat disimpulkan bahwa tidak terdapat hubungan yang signifikan antara tingkat persediaan terhadap rentabilitas pada PT Sepatu Bata Tbk.

\section{KESIMPULAN}

Berdasarkan hasil penelitian dan pembahasan mengenai pengaruh tingkat persediaan terhadap rentabilitas pada PT Sepatu Bata Tbk. maka dapat ditarik kesimpulan sebagai berikut:

Hasil analisis regresi sederhana menunjukan nilai konstanta (a) sebesar 18.72 dan nilai koefisien regresi (b) -0.23 maka rumus persamaan regresi sederhana yaitu $\mathrm{Y}=18.72-0.23 \mathrm{X}$ yang artinya apabila tidak ada nilai tingkat persediaan $(\mathrm{X}=0)$ maka nilai rentabilitas ekonomi adalah 18.72. Hasil koefisien korelasi parsial dengan nilai -0.578 menunjukan bahwa terdapat hubungan yang negatif atau berlawanan antara tingkat persediaan dan rentabilitas ekonomi. Yang artinya bahwa semakin bertambah nilai tingkat persediaan maka semakin berkurang nilai rentabilitas ekonomi. Kemudian nilai 0.578 dapat diketahui bahwa tingkat hubungan kedua variabel yaitu tingkat persediaan terhadap rentabilitas ekonomi pada PT Sepatu Bata Tbk. memiliki hubungan yang cukup kuat. Hasil koefisien determinasi menunjukan hasil sebesar $33.4 \%$ yang artinya tingkat persediaan memiliki pengaruh sebesar $33.4 \%$ terhadap rentabilitas ekonomi. Sedangkan sisanya yaitu $66.6 \%$ dipengaruhi oleh faktor lain diluar penelitian ini. Hasil uji hipotesis (uji t) menunjukan nilai $t_{\text {hitung }}$ sebesar -1.585 dan nilai $t_{\text {tabel }}$ sebesar 2.015 yang berarti bahwa $t_{\text {hitung }}$ lebih kecil dari pada $t_{\text {tabel }}\left(t_{\text {hitung }} \leq t_{\text {tabel }}\right)$ yang berarti Ho diterima dan Ha ditolak. Dengan demikian dapat disimpulkan bahwa tingkat persediaan tidak memiliki pengaruh yang signifikan terhadap rentabilitas ekonomi.Berdasarkan hasil penelitian yang diuraikan maka penulis mengajukan beberapa saran yaitu Bagi perusahaan, hendaknya mengatur dan memaksimalkan lagi persediaan yang ada sehingga dapat menghasilkan keuntungan yang maksimal terhadap perusahaan. Pada penelitian selanjutnya diharapkan dapat dilakukan dengan objek penelitian yang berbeda, dan dengan variasi variabel independen (x) yang lain sehingga dapat diperoleh hasil yang positif dan signifikan.

\section{REFERENSI}

Adawia, Popon Rabia, A. azizah dan A. (2018). Akuntansi Persediaan Dan Pengaruhnya Terhadap Laba Perusahaan Pada PT. IndoSino Agrochemical. PERSPEKTIF, XVI $(1$ Sptember 2018), 196.

Hanafi, M. M. (2010). Manajemen Keuangan. Yogjakarta: BPFE.

Hery. (2015). Laporan Analisa Keuangan. Yogjakarta: CAPS (Centre of Academic Publisihing Service).

Riyanto, B. (2016). Dasar-Dasar Pembelanjaan (Keempat). Yogjakarta: BPFE.

Sugiyono. (2016). Metode Penelitian. Kuantitatif, Kualitatif dan R\&D. Bandung: Alfabeta.

Suratminingsih. (2018). Pengaruh perputaran piutang, likuiditas, leverage dan ukuran perusahaan terhadap Profitabilitas. AKADEMIKA, 60-61.

Umar, H. (2014). Metode Penelitian untuk Tesis dan Skripsi Bisnis (7th ed.). Jakarta: PT. Raja Grafindo Persada.

\section{PROFIL PENULIS}

Popon Rabia Adawia, Penulis 1, memperoleh gelar Sarjana Ekonomi (SE) Jurusan Akuntansi, STIE YAI Jakarta dan gelar S2 dari program Pasca Sarjana Magister Manajemen Universitas Persada Indonesia YAI Jakarta. Saat ini menjadi Dosen Luar Biasa di UBSI Jakarta.

Ayu Azizah, Penulis 2, memperoleh gelar Sarjana Ekonomi (SE), Jurusan manajemen Universitas Sultan Ageng Tirtayasa, lulus 2010. Gelar S2 Magister Manajemen (MM) Universitas BSI Bandung. Saat ini menjadi Dosen Luar Biasa di UBSI Bandung. 